\title{
Teachers' Perception on the Relationship between Job Satisfaction and the Other Job-Related Outcomes: A Field Study.
}

\author{
İsmail BAKAN", Burcu ERŞAHAN**, Tuba BÜYÜKBEŞE ${ }^{* \star *}$, M. Tuncer OKUMUŞ \\ Prof. Dr, Kahramanmaras Sutcu Imam University, Faculty of Economics and Administrative Sciences. \\ E-mail: ibakan63@hotmail.com \\ "Doç. Dr, Kahramanmaras Sutcu Imam University, Faculty of Economics and Administrative Sciences. \\ E-mail: bezbebek@gmail.com \\ ${ }^{4 * *}$ Assoc. Prof. Dr. Hasan Kalyoncu University, Faculty of Economics and Administrative Sciences. \\ E-mail: tuba.buyukbese@hku.edu.tr \\ Kahramanmaras Sutcu Imam University, Graduate School of Social Sciences. \\ E-mail:mtokumus@hotmail.com
}

\begin{abstract}
This study aims to investigate the relationship between overall job satisfaction and the job-related outcomes consisting of work/family conflict, family/work conflict, role conflict, role ambiguity, workload, general stress, emotional exhaustion and employee turnover intention. Regarding this aim, the research hypotheses were developed and tested from the perspectives of teachers and education administrators working in the city of Kahramanmaras in Turkey. In order to gather the research data a survey is applied to 360 teachers and administrators selected from different school types. Results reveal that there are significant relationships and differences among participants' job satisfaction levels and their perceptions on the job-related outcomes studied.
\end{abstract}

\section{Keywords}

Job satisfaction, work/family conflict, role conflict, role ambiguity, workload, general stress, emotional exhaustion, intention to leave

\section{INTRODUCTION}

Job satisfaction is an important concept for all employees. There are personal and organizational factors affecting job satisfaction of employees and these factors affect both employees and employers positively or negatively. If an employee's job satisfaction level is low it may cause undesirable negative attitudes and behavior in the work context, such as absenteeism, external turnover, reduced productivity (Spector, 1997), commitment (Muindi, 2011). Managers and academicians interested in this subject to prevent these negative consequences, and increase job satisfaction in an organizational context. Additionally, managers are concerned for job satisfaction for two reasons. First, many consider it as a moral responsibility to maintain a high level of job satisfaction in their organizations. Second, managers are concerned about the impact of job satisfaction on an employee's performance (Arnold and Feldman,1986).

Job satisfaction has been defined by different approaches in the literature so far. For example, it is defined as the degree to which individuals feel positively or negatively about their jobs (Schermerhorn, Hunt and Osborn, 1994). Job satisfaction can also be defined as the amount of overall positive effects (or feelings) that individuals maintain toward their jobs (Arnold and Feldman, 1986). It describes an individual's comfort zone with his or her job.

Job satisfaction is related to various attitudes and management styles towards individuals (Bakan, 2009). Starting from a certain age, people spend most of everyday life at work. In this context, people whose expectations are met by his/her job, which does not only affect the economic situation of employees but also affects the emotional situation closely, are likely to be happier. Therefore, job satisfaction plays an important role in human life in both economical and psychological sense (Bakan and Buyukbese, 2004). The happier people are with their job, the more satisfied they are expected to be (Indradevi, 2012).

In today's world, Maslow's hierarchy of need theory of motivation also laid the foundation for job satisfaction theory. This theory suggests that people seek for satisfaction for five specific needs in life - physiological needs, safety needs, social needs, self-esteem needs, and self-actualization. This model served as a good basis on which early researchers could develop job satisfaction theories. Factors influencing job satisfaction are pay, promotion, recognition, working conditions, supervision and leadership, skill and abilities, organizational policies and procedures (Muindi, 2011). Similarly, six most frequently studied causes of job satisfaction are; pay, work itself, promotions, supervisions, work group and working conditions (Arnold and Feldman, 1986).

Balancing work and family is challenge in an adult's life (Anafarta, 2011). Work-family conflict exists when the demands or expectations associated with one domain are incompatible with the demands or expectations associated with the other domain (Greenhaus and Beutell, 1985; Calvo-Salguero, Carrasco-Gonzalez and Salinas-Martínez de Lecea, 2010). The increase in dual-career couples and single-parent households and the decrease in traditional, single-earner families mean that responsibilities for work, housework, and childcare are no longer confined to traditional gender roles (Byron, 2005). Further, employees find themselves struggling to juggle the competing demands of work and family (Anafarta, 2011). Long working hours, duty and heavy work load have a direct influence on work-family conflict (Boyar, Maertz, Mosley and Carr, 2008; Kim, Leong and Lee, 2005). Thus, it is essential to establish a successful balance between work and family domains 
so that several demands in both domains could be met efficiently, and the required resources could be attained and used easily (Bass, Butler, Grzywacz and Linney, 2008; Anafarta, 2011). According to the role theory, the expected relationship between work-family conflict and job satisfaction is such that an increase in work-family conflict reduces the level of satisfaction (Frone, Russell and Cooper, 1992; Kopelman, Greenhaus and Connolly,1983). For this hypothesis, negative relationship has been found in most studies (e.g. Adams, King and King, 1996; Boles, 1996; Carlson, Kacmar and Williams, 2000; Netemeyer, Boles and McMurrian, 1996; Perrewe, Hochwarter and Kiewitz, 1999), although not in all (e.g. Aryee, Luk, Leung and Lo, 1999; Lyness and Thompson, 1997; O'Driscollet, Ilgen and Hildreth , 1992; Calvo-Salgueroet al., 2010).

Teacher's job satisfaction will be very pragmatic in the following years. It will simply indicate whether the teachers like their jobs or not (because of the difficulties about their experiences in the workplace such as work/family conflict, role conflict, role ambiguity, workload, general stress, emotional exhaustion, intention to leave) (Michaelowa and Wittmann, 2002).

For several reasons, teacher's job satisfaction has always been an important issue in empirical research. Firstly, job satisfaction is considered to have an effect on teaching (e.g. Somech and Drach-Zahavy 2000; Nabi 1995; Menlo and Poppleton 1990). Secondly, it is seen as an important aspect in maintaining the stability of teaching staff. And thirdly, teacher's job satisfaction has an advantage on balancing the relationship between the family and business (Menlo and Poppleton 1990; cited in Michaelowa and Wittmann, 2002). In addition to these highly satisfied teachers are less likely to change their schools or leave the teaching profession in comparison with the ones who are dissatisfied with many areas of their business life (Choy, Bobbitt, Henke, Medrich, Horn, and Lieberman, 1993; cited in Statistical Analysis Report, 1997).

A research shows that work-family conflict is commonly seen among people who work for long hours or who have greater work load. It is also reported that the amount of the work family conflict is very important in higher job involvement and greater autonomy ( Eby et al., 2005 ; cited in Panadik, Rajab, Shah, Rahman, Yusoff and Badri, 2012).

Family-work conflict can occur in all kinds of professions, especially professions related to service, like teachers. Voydanoff (1988) presume that meeting the often incompatible demands of family and work may build teachers familywork conflict. For example, working for long hours may prevent to show adequate performance of family responsibilities (Welsh and Bierman, 2002; cited in Olorunfemi, 2009).

Related to work-family /family-work conflict and job satisfaction we propose the following hypotheses:

\section{H1: Overall job satisfaction has a negative relationship with work- family conflict.}

\section{H2: Overall job satisfaction has a negative relationship with family-work conflict.}

Individuals in organizations are exposed to a variety of expectations from both themselves and others as they carry out their organizational roles. Expectations which are in conflict may result in role conflict for the individual, while unclear or vague expectations may cause role ambiguity (Keller, 1975). Role conflict is defined as the simultaneous occurrence of two or more role pressures so that the compliance with one makes it more difficult to comply with the other (Kahn, Wolfe, Quinn, Snoek and Rosenthal, 1964), and role ambiguity is the degree to which clear information is lacking regarding the expectation associated with a role (Kahn et al., 1964; Cervoni and DeLucia-Waack, 2011). Role conflict and role ambiguity associated with low job satisfaction and dysfunctional behavior due to the stress and anxiety of role pressures (Keller, 1975).

Teaching is an occupation that demands many roles. Role demands can become stressful for a teacher when individual has conflicting expectations from the social environment and the workplace conditions (cited in Konukman, Erdoğan, Agbuğa, Zorba, Demirhan and Yılmaz, 2010). A considerable amount of research has documented both role conflict and role ambiguity as sources of job dissatisfaction. Jackson and Schuller's (1985) meta-analytic review concluded that role conflict and role ambiguity tend to be negatively associated with job satisfaction. Similarly, Behrman and Perreault (1984) pointed out that role conflict and role ambiguity are related to job satisfaction in a negative way. Schuller et al. (1977), evaluating the impact of role conflict and role ambiguity, concluded that role conflict and role ambiguity are associated with low satisfaction, absenteeism, low involvement, and tension (cited in Koustelios, Theodorakis and Goulimaris, 2004).

Thus, we propose the following hypotheses:

\section{H3: Overall job satisfaction has a negative relationship with role conflict.}

H4: Overall job satisfaction has a negative relationship with role ambiguity.

Workload is the amount of work an individual has to do. Hart and Staveland (1988) describe workload as "the perceived relationship between the amount of mental processing capability or resources and the amount required by the task". There is a distinction between the actual amount of work and the individual's perception of the workload (www.wikipedia.org)

In an occupational setting, dealing with workload can be stressful and serve as a stressor for employees. There are three aspects of workload that can be stressful.

- Quantitative workload or overload: Having more work to do than can be accomplished comfortably.

- Qualitative workload: Having work that is too difficult. 
- Underload: Having work that fails to use a worker's skills and abilities. (www.wikipedia.org)

Workload has been linked to a number of strains, including anxiety, physiological reactions such as cortisol, fatigue, backache, headache, and gastrointestinal problems (www.wikipedia.org). Workload also may affect job satisfaction. In this study we investigate the relation between workload and job satisfaction.

The workload of teachers is influenced by several factors including more formal and difficult procedures and shortage of time. In addition, teachers are not only responsible for improving their students 'knowledge but also responsible for social and emotional development of their students, thus increasing the responsibility of the teaching profession" (Peeters and Rutte, 2005 in Wafula, 2010). Current research suggests that the teaching profession becomes a profession that is prone to experience (Nurmayanti, Noermijati, Irawanto and Thoyib, 2014). Sutton (1984) signed that role demands can become stressful for a teacher when they are excessive (role overload) (cited in Koustelios et al., 2004).

Then we propose the following hypothesis:

\section{H5: Overall job satisfaction has a negative relationship with workload.}

Job stress has become an increasingly common negative outcome of today's dynamic life. "Stress is a negative reaction towards events that are thought as to tax or exceed individual coping ability" (Jehangir, Kareem, Khan, Jan and Soherwardi, 2011). Job stress is an individual experience, depending on the traits of individuals, in that not all people react to events the same way (Manthei, Gilmore, Tuck and Adair, 1996). It is known that employee's job satisfaction and job stress are related to one another (Kahn et al., 1964). The impact of stress on satisfaction is far more straightforward. Job related stress tends to decrease general job satisfaction (Jackson, 1983). Job dissatisfaction is the simplest and most obvious psychological effect of stress. Stress and dissatisfaction are directly related with one another (Cooper and Marshall, 1976). The negative relation of stress and job satisfaction is confirmed by French and Kaplan (1970) (cited in Jehangir et al., 2011).

According to a substantial body of literature, teaching can be a very stressful occupation (Mondal, Shrestha and Bhaila, 2011). Teachers encounter many potentially negative events in their everyday professional lives over which they have little or no control or power. Demands from administrators, colleagues, students, and parents compounded by work overload, student misbehavior, and a lack of recognition for accomplishments (Greenglass and Burke, 2003) are just a few examples of situations over which teacher may have little or no control. Thus, negative events over which teachers have little or no control may create distress (Ferguson, Frost and Hall, 2012). Teacher stress is defined as the experience of negative emotions resulting from a teacher's work (Kyriacou, 2001). Teacher stress may influence how effective teachers are in the classroom, with potential consequences for their students' behavior and learning. Additionally, some researchers state that teaching profession has been internationally recognized as one of the professions that dominates the highest stress level (Wafula, 2010; cited in Nurmayanti et al., 2014). Kyriacou and Sutcliffe (1978) reported that "stress is a response syndrome mediated by an appraisal of threat to the teacher's self-esteem or well-being" (cited in AlMohannadi and Capel, 2007). According to Al-farmawy (1994), Bukhet (1994), Ibrahim (1993), Khaleel (1999), Mohammed (2000) and Murad (1997) the causes of stress are as follows; pupils' behaviour; problems related to the curriculum; school facilities; workload and lack of job satisfaction.

One of the focus areas of McCormick and his colleagues' study (2006) is teaching stress and in this study four identified stress domains are tested. These domains are external (to school) domain, personal domain, student domain and school domain (management, decision-making etc.) (McCormick, Merrick, Secen and Helmreich, 2006).

Considering stres domains identified by McCormick et al. (2006), we propose the following hypotheses to test the relation between general job satisfaction and stress:

\section{H6: Overall job satisfaction has a negative relationship with student-oriented stress}

\section{H7: Overall job satisfaction has a negative relationship with school-oriented stress}

\section{H8: Overall job satisfaction has a negative relationship with external stress}

\section{H9: Overall job satisfaction has a negative relationship with personnel stress}

Burnout, or professional exhaustion syndrome, is defined as a state of emotional, mental and physical exhaustion caused by excessive and prolonged stress at work (Chennoufi, Ellouze, Cherif, Mersni and M'rad, 2012). Exhaustion is the fundamental stress component of burnout, representing a feeling of energy loss and a sense of being completely drained out of emotional and physical strength (Nagar, 2012:46). Emotional exhaustion is characterized by feelings of emotional depletion, extreme tiredness, a lack of energy and a feeling of being drained of emotional resources to cope with continuing demands (Cordes and Dougherty, 1993; Maslach, Schaufeli and Leiter, 2001; Akpınar, Taş and Okur, 2013).

Altough the importance of burnout syndrome in the educational setting is even more emphasized, teachers have to face professional burnout under various circumstances that involve feelings of confusion (Papastylianou, Kaila and Polychronopoulos, 2009). Increased emotional exhaustion has been shown to be a significant contributor to overall burnout, which is a significant threat to the field of special education (Shyman, 2010). Various studies exist especially about the emotional exhaustion of teachers (Hargreaves, 2000; Isenbarger and Zembylas, 2006; Sutton and Wheatley, 2003; Wharton, 1993; Zhang and Zhu, 2008;cited in Basım, Begenirbaş and Yalçın, 2013). Maslach et al. (2001) pointed out that emotional exhaustion is more related to burnout syndrome and teachers have the highest level of emotional exhaustion (Tsigilis, Zournatzi and Koustelios, 2011). In these studies, it was found that surface acting, arising from the emotional conflict, emotional exhaustion (Troman, 2000; Zhang and Zhu, 2008; cited in Basım et al., 2013). 
Thus, we propose the following hypothesis:

\section{H10: Overall job satisfaction has a negative relationship with emotional exhaustion.}

Intention to turnover refers to an individual's perceived probability of staying or leaving an employing organization (Cotton and Tuttle, 1986). Tett and Meyer (1993) referred to turnover intentions as a conscious and deliberate willfulness to leave the organization. Numerous researchers (Bluedorn, 1982; Kalliath and Beck, 2001; Kramer, Larish and Strayer, 1995; Price and Mueller, 1981; Saks, 1996) have attempted to answer the question of what determines people's turnover intention by investigating possible previous circumstances that lead to employees' intentions to quit. Job satisfaction is one the factors that contribute to people's intention to quit their jobs (Moore, 2001). Job satisfaction has been repeatedly identified as the main reason why employees leave their jobs (Barak, Nissly and Levin, 2001). Many studies (for example, Mobley, Horner and Hollingsworth, 1978; Price and Mueller, 1981; Shore and Martin, 1989; Aryee and Wyatt, 1991; Chan and Morrison, 2000; Ghiselli, Lopa and Bai, 2001; McBey and Karakowsky, 2001) have reported a significant negative relationship between job satisfaction and intention to leave the organization (Mahdi, Zin, Nor, Sakat and Naim, 2012).

The teachers mentioned above who have the intention to leave their jobs is becoming a primary target of school administrators, not only because of considerable cost to human resource management (Harris, James and Boonthanom, 2005). In schools, this factor poses a problem that carries unique organizational and pedagogical implications. Research has consistently shown that teachers leave their work because of lack of satisfaction (Fore, Martin, \& Bender, 2002; Guglielmi and Tatrow, 1998; Hale-Jinks, Knopf and Kemple, 2006; cited in Shapira-Lishchinsky and Rosenblatt, 2009).

Currall, Towler, Judge and Kohn (2005) found that general job satisfaction is significantly related to the intention the public school teachers who want to quit their jobs. General job satisfaction has also been found to be associated with increased intention to stay (cited in Kosi, Sulemana, Boateng and Mensah, 2015).

Moreover, Leung and Lee (2006) found, in a study of teachers in Hong Kong, that burnout predicted teachers' intentions of leaving the profession. (cited in Skaalvik and Skaalvik, 2010).

Thus, we propose the following hypothesis:

H11: Overall job satisfaction has a negative relationship with intention to leave.

\section{METHODS}

This study aims to analyze the relationships between overall job satisfaction and the job related outcomes consisting of work/family conflict, family/work conflict, role conflict, role ambiguity, workload, general stress, emotional exhaustion and employee turnover intention. The main focus of this study is to find out the differences among participants' job satisfaction levels and their perceptions on the job-related outcomes studied. Survey method is used to test the research hypotheses mentioned above. The data for testing the hypotheses were gathered by using the questionnaire. Sample schools were identified and principals of these schools were interviewed in order to apply questionnaires. The questionnaire consists of six main sections. The first section contains demographic information of the participants. In the second section, there are 8 items on work/family conflict (Hamwi, Rutherford and Boles, 2011), 5 items on family/work conflict (Netemeyer et al., 1996; Boles, Howard and Donofrio, 2001), 8 items on role conflict (Hamwi et al, 2011), and 6 items on role ambiguity (Hamwi et al.,2011). In the third section, 7 items are asked on job satisfaction of the participants (Taylor and Bowers, 1972), 2 items on workload (Conley and Woosley, 2000), and 3 items on intention to leave (Hoy, Tarter and Kottkamp,1991), along with other items to measure their condition against the variables. In the fourth section, there are 19 items on overall stress (student stress, school stress, external stress, personal stress) (McCormick et al., 2006), and 3 items on emotional exhaustion (Bhanugopan and Fish, 2006). All the construct measurements involved in this study were adapted from the previous literature. All questions of constructs were measured using a 5-point Likert scale ranging from 1 (strongly disagree) to 5 (strongly agree).

Collected data were analyzed using SPSS 21 statistical software package. First, questionnaires were subjected to reliability test and Cronbach's alpha reliability coefficient was found for each variable. Then, descriptive statistics concerning the person and institution were revealed. Correlation test identified the level and direction of the relationship between the study variables and, finally, the level of meaningful relationships/differences between variables were tested via one-way analysis of variance (ANOVA). Following to the analyses, findings obtained from the interpretation of the results of the study are presented.

\subsection{Universe Of The Study And Sampling}

The universe of this study consists of teachers and administrators in public and private $\mathrm{K} 12$ schools in the city of Kahramanmaras in Turkey. The questionnaires were applied in 17 different types of schools. A total of 380 questionnaires were collected, and 360 of them were usable for the data analysis.

Descriptive Statistics Related to Demographic Variables are shown in Table1.

Table1. Participants' demographic characteristics.

\begin{tabular}{llllll}
\hline General Information & Count & $\%$ & General Information & Count & $\%$ \\
\hline Age & & & Education & & \\
Between 20-30 & 51 & 14,2 & Associate degree & 17 & 4,7 \\
Between 31-40 & 154 & 43,0 & Bachelor's degree & 294 & 81,9
\end{tabular}




\begin{tabular}{|c|c|c|c|c|c|}
\hline Between 41-50 & 93 & 26,0 & Master's degree & 48 & 13,4 \\
\hline 51 and over & 60 & 16,8 & Doctorate & 0 & 0 \\
\hline Total & 358 & 100 & Total & 359 & 100 \\
\hline Gender & & & Professional Seniority & & \\
\hline Female & 100 & 27,8 & $1-5$ years & 26 & 7,2 \\
\hline \multirow[t]{4}{*}{ Male } & 260 & 72,2 & $6-10$ years & 67 & 18,7 \\
\hline & & & $11-15$ years & 81 & 22,6 \\
\hline & & & $16-20$ years & 79 & 22,0 \\
\hline & & & 21 and over & 106 & 29,5 \\
\hline Total & 360 & 100 & Total & 359 & 100 \\
\hline Marital Status & & & Monthly Income & & \\
\hline Single & 41 & 11,4 & $\begin{array}{l}\text { Minimum Wage and } \\
\text { lower }\end{array}$ & 2 & 0,6 \\
\hline \multirow[t]{5}{*}{ Married } & 318 & 88,6 & $1000-1500 \mathrm{TL}$ & 5 & 1,4 \\
\hline & & & $1501-2000 \mathrm{TL}$ & 60 & 16,8 \\
\hline & & & 2001-3000 TL & 236 & 65,9 \\
\hline & & & $3001-4000 \mathrm{TL}$ & 34 & 9,5 \\
\hline & & & 4001 and over & 21 & 5,9 \\
\hline Total & 359 & 100 & Total & 358 & 100 \\
\hline \multicolumn{6}{|l|}{ Job Status of Spouse } \\
\hline Working (Public Sector) & 164 & 51,3 & & & \\
\hline Working (Private Sector) & 26 & 8,1 & & & \\
\hline Does not work & 130 & 40,6 & & & \\
\hline Total & 320 & 100 & & & \\
\hline
\end{tabular}

To reveal the demographic characteristics of the participants, several questions were asked and the results are given in Table 1.

In terms of age range; $14.2 \%$ of the respondents were in $20-30$ range, $43 \%$ in $31-40,26 \%$ in $41-50$, and $16.8 \%$ of them were 51 and older. The highest rate is in the $31-40$ age range with $43 \%$. Participants are accumulated in 31-50 range with $69 \%$.

$72.2 \%$ of the participants are male while $27.8 \%$ are female. $88.6 \%$ of the participants were married while $11.4 \%$ of them were single. As for the spouse's job status, $51.3 \%$ were working in the public sector, $8.1 \%$ in the private sector, and $40.6 \%$ of them do not work. According to the data on participants, a large proportion of spouses either works in the public sector or does not work at all. The rate of spouses working in the private sector is quite low, $8.1 \%$.

As far as educational status of the participants is concerned, $4.7 \%$ had associate degree, $81.9 \%$ bachelor's degree, $13.4 \%$ master's degree and none had doctorate degree. While bachelor level graduates yield the highest rate of $81.9 \%$, associate degree holders share the lowest number in the study group with $4.7 \%$. Since participants were teachers, a high rate of bachelor degree holders was expected in the study group. Associate degrees probably belong to the teachers with long durations of tenure. High number of master's degree with $13.4 \%$ suggests that teachers attach importance to graduate studies. Although it is not a requirement for their profession, they continue graduate studies on their own will. Lack of participants who did not study at doctoral level does not mean that teachers do not pursue doctoral degree. However, it means that they do not work in these schools.

Participants' service time ratios were $7.2 \%$ for $1-5$ years, $18.7 \%$ for $6-10$ years, $22.6 \%$ for $11-15$ years, $22 \%$ for $16-20$ years and $29.5 \%$ for 21 years and over. While $1-5$ years range, $7.2 \%$ is less than other categories, $11-15$ years and $16-20$ years emerged nearly at the same rate.

Monthly income distribution of the participants were $0.6 \%$ minimum wage or less, $1.4 \%$ in $1000-1500$ TL range, $16.8 \%$ between 1501 and 2000TL, 65.9\% between 2001 and 3000TL, 9.5\% between 3001 and 4000TL, and 5.9\% over 4000 . Monthly income of the respondents are accumulated in the range of 1501-3000TL.

\subsection{The Scale Reliability Of The Research}

Reliability analysis demonstrated that alpha value $(\alpha)$ of overall job satisfaction, which consists of 7 questions, is 0.822 ; work / family conflict, which consists of 8 questions, is 0.873 ; family / work conflict, which consists of 5 questions, is 0.861 ; role conflict, which consists of 8 questions, is 0.829; role ambiguity, which consists of 6 questions is 0.891; workload, which consists of 2 questions, is 0.755 ; intention to leave, which consists of 3 questions is 0.884 . Alpha value ( $\alpha$ ) of student stress consisting of 4 questions was found to be 0.845 ; school stress consisting of 5 questions was 0.777 ; external 
stress consisting of 5 questions was 0.860 ; personal stress consisting of 5 questions was 0.727 ; emotional exhaustion consisting of 3 questions was 0.866 . All scales were over confidence limits of 0.70 and most of them were above 0.80 . This shows the high reliability of the research scales and also variables.

The results of the reliability analysis are shown in Table 2.

Table 2.Reliability table.

\begin{tabular}{lll}
\hline \multicolumn{1}{c}{ Variables } & $\begin{array}{l}\text { Number of } \\
\text { Items }\end{array}$ & $\begin{array}{l}\text { Cronbach } \\
\text { Alpha Value }\end{array}$ \\
\hline Overall Job Satisfaction & 7 &, 822 \\
\hline Work/Family Conflict & 8 &, 873 \\
\hline Family/Work Conflict & 5 &, 861 \\
\hline Role Conflict & 8 &, 829 \\
\hline Role Ambiguity & 6 &, 891 \\
\hline Workload & 2 &, 755 \\
\hline Student Stress & 4 &, 845 \\
\hline School Stress & 5 &, 777 \\
\hline External Stress & 5 &, 860 \\
\hline Personal Stress & 5 &, 727 \\
\hline Emotional Exhaustion & 3 &, 866 \\
\hline Intention to Leave & 3 &, 884 \\
\hline
\end{tabular}

\section{3. RELATIONSHIP BASED RESULTS}

\subsection{Correlation Test}

Correlation test is used to determine the intensity and direction of test variables without considering the dependencies of the variables. The method of Pearson correlation analysis is used to analyze the degree of importance of relations between "overall job satisfaction" and "work / family conflict, family / work conflict, role conflict, role ambiguity, workload, general stress (student stress, school stress, external stress, personal stress), emotional exhaustion and intention to leave". In other words, with correlation test it is aimed to find out the direction and strength of the relationships among the research variables in this study.

Table 3 displays the results of Pearson correlation analysis for the study variables.

Table3.Correlation matrix for the variables.

\begin{tabular}{|c|c|c|c|c|c|c|c|c|c|c|c|c|}
\hline & 1 & 2 & 3 & 4 & 5 & 6 & 7 & 8 & 9 & 10 & 11 & 12 \\
\hline 1 & 1 & & & & & & & & & & & \\
\hline 2 &,$- 153^{* *}$ & 1 & & & & & & & & & & \\
\hline 3 &,$- 200^{\star *}$ & ,326** & 1 & & & & & & & & & \\
\hline 4 &,$- 249^{\star *}$ &, $456^{* \star}$ &, $300^{\star *}$ & 1 & & & & & & & & \\
\hline 5 &, $352^{* *}$ &,- 094 &,$- 277^{\star *}$ &,$- 263^{\star *}$ & 1 & & & & & & & \\
\hline 6 &,$- 226^{\star *}$ & ,333 &, $348^{\star *}$ &, $525^{\star *}$ &,$- 200^{\star *}$ & 1 & & & & & & \\
\hline 7 &,$- 113^{\star}$ & ,258 &, $178^{\star *}$ & $318^{* \star}$ &, 015 &, $294^{\star *}$ & 1 & & & & & \\
\hline 8 &,$- 264^{\star *}$ &, $175^{\star \star}$ &, $383^{* *}$ &, $377^{\star *}$ &,$- 232^{\star *}$ &, $318^{* *}$ &, $356^{\star *}$ & 1 & & & & \\
\hline 9 &,$- 171^{\star *}$ & ,192** &, $153^{\star *}$ & ,203** &,- 033 & ,180** &, $336^{\star *}$ & ,208** & 1 & & & \\
\hline 10 &,$- 133^{\star}$ &, $179^{* \star}$ &, $422^{* *}$ & ,209** &,$- 266^{\star *}$ &, $165^{\star \star}$ &, $159^{* *}$ &, $283^{* *}$ & ,012 & 1 & & \\
\hline 11 &,$- 226^{\star *}$ &, $410^{* *}$ &, $363^{* *}$ &, $381^{* *}$ &,$- 170^{\star *}$ & , $373^{* *}$ &, $352^{* *}$ &, $337^{* *}$ & $194^{* *}$ &, $341^{* *}$ & 1 & \\
\hline 12 &,$- 269^{\star *}$ & ,293** &, $301^{* *}$ &, $353^{\star *}$ &,$- 234^{\star *}$ &, $353^{\star \star}$ &, $242^{\star *}$ &, $345^{\star *}$ & , $170^{\star \star}$ &, $256^{\star \star}$ & ,414** & 1 \\
\hline
\end{tabular}

1=Overall Job Satisfaction,

2= Work/Family Conflict,

3= Family/Work Conflict,

4= Role Conflict,

$5=$ Role Ambiguity,

$6=$ Workload, 
$7=$ Student Stress,

$11=$ Emotional Exhaustion,
$9=$ External Stress,

$8=$ School Stress,

$12=$ Intention to leave

Note: ${ }^{* *} p \leq 0.01,{ }^{*} p \leq 0.05$

According to the results of the analysis, there is a positive meaningful relation between overall job satisfaction and the role ambiguity, and a negative meaningful relation ( $p \leq 0.01$ or $p \leq 0.05$ ) between overall job satisfaction and the following variables: work-family conflict (with a coefficient of -0.153$)$; family-work conflict $(-0.200)$; role conflict $(-0.249)$; work load ($0.226)$; student stress $(-0.113)$; school stress $(-0.264)$; external stress ( -0.171$)$; personal stress $(-0.133)$; emotional exhaustion (-0.226); intent to leave (-0.269).

The relation between overall job satisfaction and role ambiguity reached the highest value with 0.352 in Table 3 . In addition, the relationship between overall job satisfaction and student stress is the lowest with a value of -0.113 . All variables are significantly related to each other.

An interesting finding of the correlation analysis is that, overall job satisfaction is positively related to role ambiguity. In the literature some studies also (example Kahn et al.,1964; Keller, 1975; Locke, 1976, Ulutürk and Ceylan, 2006) found negative relation between role ambiguity and job satisfaction. In our study role ambiguity was highly and significantly related to overall job satisfaction but positively.

\subsection{Perspectives Of Teachers With Respect To Job Satisfaction Levels}

61 propositions, offered regarding teachers' job satisfaction and other job related outcomes, are combined with SPSS Compute Mean option. Based on this combination, regarding job satisfaction it was suggested that teachers' satisfaction levels could be grouped into five levels: "very low level of satisfaction", "low level of satisfaction", "medium level of satisfaction", "high level of satisfaction", and "very high level of satisfaction". In this study, ANOVA test was used to see any significant differences in the levels of perception of the participants about work/family conflict, family/work conflict, role conflict, role ambiguity, workload, student stress, school stress, external stress, personal stress, emotional exhaust, intention to leave by taking account the teachers with five different satisfaction levels.

The results of the analysis show a significant difference in their perspective on work-family and family-work conflict among five groups divided in accordance with their job satisfaction levels. A relation between job satisfaction level and workfamily and family-work conflict was found. As the teachers' job satisfaction increases, their participation to work-family conflict and family-work conflict proposition decreases. Table 4 displays the ANOVA test results for teachers' perspectives on work-family and family-work conflict in accordance to job satisfaction levels.

Table4.Teachers' perspectives on work-family and family-work conflict according to job satisfaction levels.

\begin{tabular}{|c|c|c|c|c|c|}
\hline Work-Family and Family-Work Conflict & $\mathbf{N}$ & WA & SD & $\mathbf{F}$ & Sig. \\
\hline \multirow[t]{5}{*}{ Work-Family Conflict } & $22^{*}$ & 2,7833 & 1,22245 & \multirow[t]{6}{*}{5,127} & \multirow[t]{6}{*}{001} \\
\hline & $46^{* *}$ & 3,2558 & ,95015 & & \\
\hline & $137^{* * *}$ & 3,0179 & ,87088 & & \\
\hline & $94^{\star * * *}$ & 2,8131 & ,85733 & & \\
\hline & $61^{\star \star \star \star \star}$ & 2,5117 & 1,05460 & & \\
\hline Total & 360 & 2,8947 & ,95609 & & \\
\hline \multirow[t]{5}{*}{ Family-Work Conflict } & $22^{*}$ & 2,3636 & 1,16723 & \multirow[t]{6}{*}{5,803} & \multirow[t]{6}{*}{,000 } \\
\hline & $46^{\star \star}$ & 2,0717 & ,92920 & & \\
\hline & $136^{\star * *}$ & 2,0934 & ,74587 & & \\
\hline & $94^{\star * \star *}$ & 2,0986 & ,76873 & & \\
\hline & $61^{* * * * *}$ & 1,5934 & ,74383 & & \\
\hline Total & 359 & 2,0236 & ,82870 & & \\
\hline
\end{tabular}

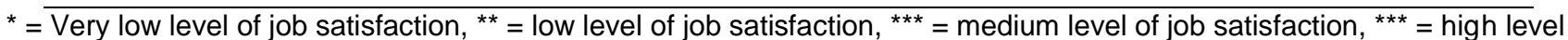
of job satisfaction, ${ }^{* * \star * *}=$ very high level of job satisfaction

It is evident from the results of analysis that five groups divided based on their job satisfaction levels indicate a significant difference in their perspective of job characteristics (role conflict, role ambiguity and workload). In addition, a relation between job satisfaction level and job characteristics exists. As the teachers' job satisfaction increases, their participation in propositions on role conflict and workload decreases. But the teachers' job satisfaction increases parallel to role ambiguity. Teachers' perspectives on job characteristics based on their job satisfaction levels are shown in Table 5.

Table 5.Teachers' perspectives on job characteristics based on job satisfaction level.

\begin{tabular}{llllll}
\hline Job Characteristics & N & WA & SD & F & Sig. \\
\hline Role Conflict & $22^{*}$ & 2,4375 & 1,06608 & 9,271 &, 000 \\
& $46^{* *}$ & 2,8377 &, 85550 & & \\
& $137^{* *}$ & 2,5560 &, 69505 & &
\end{tabular}




\begin{tabular}{|c|c|c|c|c|c|}
\hline \multirow[b]{3}{*}{ Total } & $94^{\star \star \star \star}$ & 2,2965 & \multicolumn{3}{|l|}{,71195 } \\
\hline & $61^{\star \star \star \star *}$ & 2,0117 & \multicolumn{3}{|l|}{,84173 } \\
\hline & 360 & 2,4248 & ,80789 & & \\
\hline \multirow[t]{5}{*}{ Role Ambiguity } & $22^{*}$ & 2,9523 & 1,15955 & \multirow[t]{6}{*}{14,273} & \multirow[t]{6}{*}{,000 } \\
\hline & $46^{* *}$ & 3,6906 & ,82230 & & \\
\hline & $137^{\star \star *}$ & 3,7562 & ,75470 & & \\
\hline & $94^{\star \star \star \star}$ & 3,8489 & ,74298 & & \\
\hline & $61^{\star \star \star \star *}$ & 4,3514 & ,72277 & & \\
\hline Total & 360 & 3,8238 & ,84114 & & \\
\hline \multirow[t]{5}{*}{ Workload } & $22^{*}$ & 2,3182 & 1,05272 & \multirow[t]{6}{*}{7,912} & \multirow[t]{6}{*}{,000 } \\
\hline & $46^{* *}$ & 2,9457 & 1,30055 & & \\
\hline & $137^{* * *}$ & 2,5657 & 1,02867 & & \\
\hline & $94^{\star \star \star \star}$ & 2,2819 & ,88159 & & \\
\hline & $61^{* * * * *}$ & 1,9180 & ,95385 & & \\
\hline Total & 360 & 2,4153 & 1,05973 & & \\
\hline
\end{tabular}

As a result of the survey, a relationship between job satisfaction level and organizational stress was found. Regarding teachers' perspectives on organizational stress aspects, significant differences among the five groups were observed. As the participants' job satisfaction increases their organizational stress (student stress, school stress, external stress, personal stress) decreases (see Table 6).

Table 6.Teachers' perspectives on organizational stress based on job satisfaction levels.

\begin{tabular}{|c|c|c|c|c|c|}
\hline Organizational Stress & $\mathbf{N}$ & WA & SD & $\mathbf{F}$ & Sig. \\
\hline \multirow[t]{5}{*}{ Student Stress } & $22^{*}$ & 2,8523 & 1,20924 & 4,630 & 001 \\
\hline & $46^{\star \star}$ & 3,5453 & 1,13280 & & \\
\hline & $136^{* * *}$ & 3,2402 & ,95150 & & \\
\hline & $94^{* \star * *}$ & 3,0443 & ,92649 & & \\
\hline & $60^{\star \star \star \star \star}$ & 2,7833 & 1,12791 & & \\
\hline Total & 358 & 3,1276 & 1,03813 & & \\
\hline \multirow[t]{5}{*}{ School Stress } & $22^{*}$ & 2,4909 & ,99662 & 9,943 & ,000 \\
\hline & $46^{\star \star}$ & 2,8217 & 1,14094 & & \\
\hline & $137^{* * *}$ & 2,5987 & ,70920 & & \\
\hline & $94^{* * * *}$ & 2,3126 & 61748 & & \\
\hline & $61^{* \star * * *}$ & 1,9661 & ,85363 & & \\
\hline Total & 360 & 2,4387 & ,83858 & & \\
\hline \multirow[t]{5}{*}{ External Stress } & $22^{*}$ & 3,8409 & 1,26063 & 5,661 & ,000 \\
\hline & $45^{\star *}$ & 4,1289 & 1,03235 & & \\
\hline & $135^{* * *}$ & 3,8977 & ,86858 & & \\
\hline & $94^{\star \star \star \star}$ & 3,7920 & ,76335 & & \\
\hline & $61^{* * * * *}$ & 3,3295 & 1,08556 & & \\
\hline Total & 357 & 3,7984 & ,95687 & & \\
\hline \multirow[t]{5}{*}{ Personal Stress } & $22^{*}$ & 2,3705 & ,89185 & 2,409 & ,049 \\
\hline & $45^{\star *}$ & 2,2111 & ,87027 & & \\
\hline & $136^{\star * *}$ & 2,0004 & 65213 & & \\
\hline & $94^{* \star \star *}$ & 2,1027 & ,72466 & & \\
\hline & $61^{* * * * *}$ & 1,9016 & ,80721 & & \\
\hline Total & 358 & 2,0596 & ,74980 & & \\
\hline
\end{tabular}

${ }^{*}=$ Very low level of job satisfaction, ${ }^{* *}=$ low level of job satisfaction, ${ }^{* \star *}=$ medium level of job satisfaction, ${ }^{* \star *}=$ high level of job satisfaction, ${ }^{* * * * *}=$ very high level of job satisfaction

A relationship between job satisfaction level and emotional exhaust is also observed. As the job satisfaction levels of participants increase, participations to propositions regarding emotional exhaust decrease. The test results regarding teachers' perspectives on emotional exhaust based on their level of job satisfaction are given in Table 7. 
Table 7.Teachers' perspectives on emotional exhaustion based on job satisfaction levels.

\begin{tabular}{llllll}
\hline Emotional Exhaustion & $\mathbf{N}$ & WA & SD & F & Sig. \\
\hline Emotional Exhaustion & $22^{*}$ & 2,3182 & 1,15689 & 10,221 &, 000 \\
& $45^{\star *}$ & 2,8148 & 1,39182 & & \\
& $136^{\star * *}$ & 2,6275 &, 94199 & & \\
& $94^{* * *}$ & 2,2074 &, 88519 & & \\
& $61^{* * * *}$ & 1,7760 &, 96939 & & \\
Total & 358 & 2,3766 & 1,06426 & &
\end{tabular}

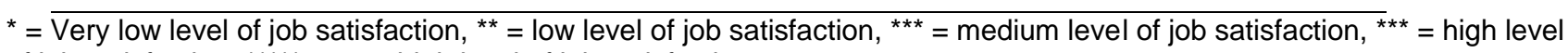
of job satisfaction, ${ }^{* * \star *}=$ very high level of job satisfaction

Table 8 provides the results of teachers' perspectives on intention to leave depending on their job satisfaction levels. The results of analysis points to significant differences on intention to leave perspectives among five different job satisfaction groups. As the job satisfaction levels of teachers increase, their participations to propositions on intention to leave decrease.

Table 8.Teachers' perspectives on intention to leave based on job satisfaction level.

\begin{tabular}{|c|c|c|c|c|c|}
\hline Intention to Leave & $\mathbf{N}$ & WA & SD & $\mathbf{F}$ & Sig. \\
\hline \multirow[t]{5}{*}{ Intention to Leave } & $22^{*}$ & 2,2121 & 1,25797 & 11,316 & ,000 \\
\hline & $46^{\star *}$ & 2,8261 & 1,17744 & & \\
\hline & $137^{* * *}$ & 2,4453 & ,96742 & & \\
\hline & $94^{* * * *}$ & 2,1152 &, 90334 & & \\
\hline & $61^{* * \star * *}$ & 1,6339 & ,97507 & & \\
\hline Total & 360 & 2,2560 & 1,05715 & & \\
\hline
\end{tabular}

${ }^{*}=$ Very low level of job satisfaction, ${ }^{* *}=$ low level of job satisfaction, ${ }^{* * *}=$ medium level of job satisfaction, ${ }^{* * *}=$ high level of job satisfaction, ${ }^{* \star \star * *}=$ very high level of job satisfaction

\section{RESULTS AND DISCUSSION}

This study aims to analyze the relationship between overall job satisfaction and the job related outcomes consisting of work/family conflict, family/work conflict, role conflict, role ambiguity, workload, student stress, school stress, external stress, personal stress, emotional exhaustion, intention to leave variables. A survey method is used to reveal the results and questionnaires are applied to 360 teachers from selected schools.

All scales used to measure the study variables are obtained above the confidence limit of 0.70 while most of them are over 0.80 , which show that the scales regarding the variables are highly reliable.

Pearson correlation analysis was used to analyze the relations between "overall job satisfaction" and job-related outcomes "work/family conflict, family/work conflict, role conflict, role ambiguity, workload, student stress, school stress, external stress, personal stress, emotional exhaustion, intention to leave" and the degree of importance of these relations.

To summarize the results, overall job satisfaction is positively related with role ambiguity and negatively related ( $p \leq 0.01$ or $p \leq 0.05$ ) with work/family conflict, family/work conflict, role conflict, workload, school stress, external stress, emotional exhaustion and intention to leave. All of our hypotheses are accepted, with the exception of hypothesis 4 .

H1: Overall Job Satisfaction has a negative relationship with work- family conflict.(Accepted)

H2: Overall Job Satisfaction has a negative relationship with family-work conflict. (Accepted)

H3: Overall Job Satisfaction has a negative relationship with role conflict. (Accepted)

H4: Overall Job Satisfaction has a negative relationship with role ambiguity.(Declined)

H5: Overall Job Satisfaction has a negative relationship with workload. (Accepted)

H6: Overall Job Satisfaction has a negative relationship with student-oriented stress. (Accepted)

H7: Overall Job Satisfaction has a negative relationship with school-oriented stress. (Accepted) 
8: Overall Job Satisfaction has a negative relationship with external stress. (Accepted)

H 9: Overall Job Satisfaction has a negative relationship with personnel stress. (Accepted)

H10: Overall Job Satisfaction has a negative relationship with emotional exhaustion. (Accepted)

H11: Overall Job Satisfaction has a negative relationship with intent to leave. (Accepted)

According to all these data;

- Statistically significant relationships were found between overall job satisfaction and the job-related outcomes which are work/family conflict, family/work conflict, role conflict, role ambiguity, workload, student stress, school stress, external stress, personal stress, emotional exhaust, intention to leave.

- Overall job satisfaction is mostly related to role ambiguity with a value of 0.352 . In addition, the relationship between overall job satisfaction and student stress is the lowest with a value of -0.113 . All study variables have significant relationships with job satisfaction.

- Overall job satisfaction is positively related to role ambiguity.

- Overall job satisfaction is negatively related to work-family conflict, family-work conflict, role conflict, workload, student stress, school stress, external stress, personal stress, emotional exhaustion, intention to leave accomplishment reduction.

The propositions prepared for teachers' job satisfaction are combined with SPSS Compute Mean option. It was observed that they could be categorized into five satisfaction levels: "very low level of job satisfaction", "low level of job satisfaction", "medium level of job satisfaction", "high level of job satisfaction", and "very high level of job satisfaction". Obtained data was analyzed with ANOVA test to determine the perception differences among job satisfaction groups.

According to the results,

- Statistically significant differences in the participants' perceptions on job related outcomes (work/family conflict, family/work conflict, role conflict, role ambiguity, workload, student stress, school stress, external stress, personal stress, emotional exhaust, intention to leave) exist among five groups which are divided regarding their level of job satisfaction.

- As the overall job satisfaction level increases, participation to propositions on job-related outcomes decreases (with the exception of role ambiguity).

This study correlated overall job satisfaction with other undesirable job related outcomes with the perceptions of teachers. In search of excellence, organizations pay more attention to increase their employee's job satisfaction in order to reach organizational aims. Effective human resource practices should therefore strive to let employees know what is expected of them in the performance of their organizational roles (Keller, 1975). Work/family conflict, family/work conflict, role conflict, role ambiguity, workload, student stress, school stress, external stress, personal stress, emotional exhaust, intention to leave are clearly linked with job satisfaction. Improving job satisfaction may be useful for preventing or minimizing undesirable job related outcomes.

\section{References}

1. Adams, G. A., King L.A., \& King D.W. (1996). Relationships of job and family involvement, family social support, and work-family conflict with job and life satisfaction. Journal of Applied Psychology, 81(4), 411-420.

2. Akpınar, A.T., Taş Y., \& Okur M.E. (2013). The effect of job satisfaction and emotional exhaustion on affective commitment of emergency services employees. British Journal of Economics, Finance and Management Sciences, 7(2), 169-176.

3. Al-farmawy, H.A. (1994). The teacher's stress level. Paper presented at the Second Egyptian Education Summit.

4. Al-Mohannadi, A., \& Capel, S., (2007). Stress in physical education teachers in Qatar. Social Psychology of Education, 10 (1), 55-75.

5. Anafarta, N. (2011), The relationship between work-family conflict and job satisfaction: A structural equation modeling (SEM) approach. International Journal of Business and Management, 6(4), 168-177.

6. Arnold H.A., \& Feldman D.C. (1986). Organizational Behavior. Singapore: Mcgraww-Hill International Editions.

7. Aryee S., \& Wyatt T. (1991). Antecedents of organizational commitment and turnover intentions among professional accountants in different employment settings in Singapore. Journal of Social Psychology, 13, 545556.

8. Aryee S., Luk V., Leung A., \& Lo, S. (1999). Role stressors, inter-role conflict, and well-being: the moderating influence of spousal support and coping behaviors among employed parents in Hong Kong. Journal of Vocational Behavior, 54, 259-278. 
9. Bakan, İ. (2009). Çalışanların ‘yöneticilerden tatmin' ve 'genel tatmin' düzeyleri ile demografik özellikleri arasındaki ilişkiler: Bir alan çalışması. Marmara Üniversitesi Sosyal Bilimler Enstitüsü Hakemli Öneri Dergisi, 8(31), 53-67.

10. Bakan, İ., \& Büyükbeşe T. (2004). The relationship between organizational communication and aspects of job satisfaction: A field study for academic organizations. Akdeniz Üniversitesi Iktisadi ve Idari Bilimler Dergisi, 4(7), 1-30.

11. Barak, M.E., Nissly J.A., \& Levin, A. (2001). Antecedents in retention and turnover among child welfare, social work, and other human service employees: What can we learn from past research? A review and metanalysis. The Social Service Review, 75, 625-645.

12. Basım, H.N., Beğenirbaş, M., \& Yalçın, R.C. (2013). Effects of Teacher Personalities on Emotional Exhaustion: Mediating Role of Emotional Labor. Educational Sciences: Theory \& Practice, 13(3), 1488-1496.

13. Bass, L.B., Butler, B.A., Grzywacz, G.J., \& Linney D.K. (2008). Work-family conflict and job satisfaction: family resources as a buffer. Journal of Family and Consumer Sciences, 10(1), 24-30.

14. Behrman, D., \& Perreault, W. (1984). A role stress model of the performance and satisfaction of industrial salesperson. Journal of Marketing, 48, 9-21.

15. Beutell, N.J., \& Wittig-Berman, U. (1999). Predictors of work-family conflict and satisfaction with family, job, career, and life. Psychological Reports, 85(3), 893-903.

16. Bhanugopan, R., \& Fish, A.J. (2006). An empirical investigation of job burnout among expatriates in Papua New Guinea. Personnel Review, 35(4), 449-468.

17. Bluedorn, A.C. (1982). A unified model of turnover from organizations. Human Relations, 35, 135-153.

18. Boles, J.S., (1996). Influences of work-family conflict on job satisfaction, life satisfaction, and quitting intentions among business owners: The case of family-operated businesses. Family Business Review, 9, 61-74.

19. Boles, J.S., Howard, W.G., \& Donofrio, H.H. (2001). An investigation into the inter-relationships of work-family conflict, family-work conflict and work satisfaction. Journal of Managerial Issues, 13(3), 376-90.

20. Boyar, S.L., Maertz, Jr.C.P., Mosley, Jr.D.C. \& Carr, J.C. (2008). The impact of work/family demand on workfamily conflict. Journal of Managerial Psychology, 23(3), 215-235.

21. Bukhet, M. (1994). Stress and its relation with self improvement. Unpublished MA Thesis, Ain Shames University, Cairo, Egypt.

22. Byron, D. (2005). A meta-analytic review of work-family conflict and its antecedents. Journal Of Vocational Behavior, 67, 169-198.

23. Calvo-Salguero, A., Carrasco-Gonzalez, A.M., \& Salinas-Martínez de Lecea, J.M., (2010). Relationship between work-family conflict and job satisfaction: The moderating effect of gender and the salience of family and work roles. African Journal Of Business Management, 4(7), 1247-1259.

24. Carlson, S.D., Kacmar, K.M., \& Williams, J.L. (2000). Construction and initial validation of a multidimensional measure of work-family conflict. Journal of Vocational Behaviour, 56,249-276.

25. Cervoni, A. \& De Lucia-Waack, J. (2011). Role conflict and ambiguity as predictors of job satisfaction in high school counselors. Journal of School Counseling, 9(1),1-30.

26. Ceylan, A., \& Ulutürk, H. (2006). Rol belirsizliği, rol çatışması, iş tatmini ve performans arasındaki ilişkiler. Doğuş Üniversitesi Dergisi, 7(1), 48-58.

27. Chan, E., \& Morrison, P. (2000). Factors influencing the retention and turnover intentions of registered nurses in a Singapore hospital. Nursing and Health Science, 2(2), 113-121.

28. Chennoufi, L., Ellouze, F., Cherif, W., Mersni, M., \& M'rad, M.F. (2012.) Stress and burnout among Tunisian teachers. Encephale, 38(6), 480-7. Epub 2012 Jul 11.

29. Choy, S.P., Bobbitt, S.A., Henke, R.R., Medrich, E.A., Horn, LJ., \& Lieberman, J. (1993). America's Teachers: Profile of a Profession. Washington, DC: U.S. Department of Education, Office of Educational Research and Improvement, National Center for Education Statistics, NCES 93-025.

30. Conley, S. \& Woosley, S.A. (2000). Teacher role stress, higher order needs and work outcomes. Journal of Educational Administration, 38(2), 179-201.

31. Cooper, C.L., \& Marshall, J. (1976). Occupational sources of stress: A review of literature relating to coronary heart disease and mental ill health. Journal of occupational and Organizational Psychology, 49(1), 11-28.

32. Cordes, C.L., \& Dougherty, T.W. (1993). A review and an integration of research on job burnout. Academy of Management Review, 18(4), 621-656. 
33. Cotton, J., \& Tuttle, J. (1986). Employee turnover: A meta-analysis and review with implication for research. Academy of Management Review, 11(1), 55-70.

34. Eby, L.T., Casper, W.J., Lockwood, A., Bordeaux, C. \& Brinley, A. (2005). Work and family research in IO/OB: content analysis and review of the literature (1980-2002), Journal of Vocational Behavior, 66(1): p. 124-197.

35. Eren, E. (2010). Örgütsel Davranış ve Yönetim Psikolojisi. İstanbul: Beta publishers

36. Ferguson, K., Frost, L., \& Hall, D. (2012). Predicting teacher anxiety, depression and satisfaction. Journal Of Teaching And Learning, 8(1), 27-42.

37. Fore, C., Martin, C., \& Bender, W.N. (2002). Teacher burnout in special education: The causes and the recommended solutions. High School Journal, 86(1), 36-44.

38. Frone, M.R., Russell, M., and Cooper, M.L. (1992). Antecedents and outcomes of work-family conflict: Testing a model of the work-family interface. Journal of Applied Psychology, 77, 65-78.

39. Ghiselli, R.F., Lopa, J.M.L., \& Bai, B. (2001). Job satisfaction, life satisfaction and turnover intent: Among foodservice managers. Cornell University The Cornell Hotel and restaurant Administration Quarterly, 42(2), 28-37.

40. Greenglass, E.R., \& Burke, R.J. (2003). Teacher stress. In: Dollard M F, Winefield H and Winefield HR (eds.) Occupational stress in the service professions. New York: Taylor and Francis, pp. 213-236.

41. Greenhaus, H.J., \& Beutell, N.J. (1985). Sources of conflict between work and family roles. The Academy of Management Review, 10(1),76-88.

42. Guglielmi, R.S., \& Tatrow, K. (1998). Occupational stress, burnout, and health in teachers: A methodological and theoretical analysis. Review of Educational Research, 68(1), 61-99.

43. Hale-Jinks, C., Knopf, H., \& Kemple, K. (2006). Tackling teacher turnover in child care: Understanding causes and consequences, identifying solutions. Childhood Education, 82(4), 219-226.

44. Hamwi, G.A., Rutherford, B.N., \& Boles, J.S. (2011), Reducing emotional exhaustion and increasing organizational support. Journal of Business \& Industrial Marketing, 26(1), 4-13.

45. Hargreaves, A. (2000). Mixed emotions: teachers' perceptions of their interactions with students. Teaching and Teacher Education, 16, 811-826.

46. Harris, K.J., James, M.L., \& Boonthanom, R. (2005). Perceptions of organizational politics and cooperation as moderators of the relationship between stress and intent to turnover. Journal of Managerial Issues, 17, 26-42.

47. Hart, S.G., \& Staveland L.E. (1988). Development of NASA-TLX (Task Load Index): Results of empirical and theoretical research. In P. A. Hancock and N. Meshkati (Eds.) Human Mental Workload. Amsterdam: North Holland Press.

48. Hoy, W.K., Tarter, C.J., \& Kottkamp, R.B. (1991). Open schools/healthy schools: measuring organizational climate. Hardcover: Corwin Press/Sage Publication.

49. Ibrahim, S.I. (1993). Stress for male and female PE teachers. Unpublished Master thesis, Education College, Al Zagazig University, Al Zagazig, Egypt.

50. Indradevi, R. (2012). The impact of psychological empowerment on job performance and job satisfaction in Indian software companies. Excel International Journal Of Multidisciplinary Management Studies, 2(4), 36-48.

51. Isenbarger, L., \& Zembylas, S.M. (2006). The emotional labor of caring in teaching. Teaching and Teacher Education, 22, 120-134.

52. Jackson, S.E. (1983). Participation in decision making as a strategy for reducing job related strain. Journal of Applied Psychology, 68(1): 3-19.

53. Jackson, S., and Schuller, R. (1985). A meta-analysis and conceptual critique of research on role ambiguity and role conflict in work settings. Organizational Behavior and Human Decision Processes, 36, 16-78.

54. Jehangir, M., Kareem, N., Khan, A., Jan, M.T., \& Soherwardi, S, (2011,) Effects of job stress on job performance \& job satisfaction. Interdisciplinary Journal of Contemporary Research in Business, 3(7),453-465.

55. Kahn, R.L., Wolfe, D.M., Quinn, R.P., Snoek, J.D., \& Rosenthal, R.A., (1964). Organizational Stress: Studies In Role Conflict And Ambiguity. New York: Wiley

56. Kalliath, T.J., \& Beck, A. (2001). Is the path to burnout and turnover paved by a lack of supervisory support: A structural equations test. New Zealand Journal of Psychology, 30,72-78.

57. Keller, R.T. (1975). Role conflict and ambiguity: Correlates with job satisfaction and values. Personnel Psychology, 28, 57-64.

58. Khaleel, S. (1999). Building a measure for stress and burnout for physical education. Unpublished PhD dissertation, Al Zagazig University, Al Zagazig, Egypt. 
59. Kim, W.G., Leong, J.K., \& Lee, Y.K. (2005). Effect of service orientation on job satisfaction, organizational commitment, and intention of leaving in a casual dining chain restaurant. International Journal of Hospitality Management, 24(2), 171-193.

60. Konukman, F., Agbuğa, B., Erdoğan, Ş., Zorba, E., Demirhan,G., \& Yılmaz, İ., (2010), Teacher-coach role conflict in school-based physical education in USA: a literature review and suggestions for the future, Biomedical Human Kinetics, 2, 19 - 24, http://www.researchgate.net/publication/240311801.

61. Kopelman, R.E., Greenhaus, J.H., \& Connolly, T.F. (1983). A model of work, family, and interrole conflict: A construct validation study, Organizational Behavior and Human Performance, 32(2), 198-215.

62. Kosi, I., Sulemana, I., Boateng, J.S., \& Mensah, R. (2015). Teacher motivation and job satisfaction on intention to quit: An empirical study in public second cycle schools in Tamale metropolis, Ghana. International Journal of Scientific and Research Publications, 5,(5), 1-8.

63. Koustelios, A., Theodorakis, N. \& Goulimaris, D. (2004). Role ambiguity, role conflict and job satisfaction among physical education teachers in Greece, International Journal of Educational Management, 18(2), 87-92.

64. Kramer, A.F., Larish, J.F., \& Strayer, D.L. (1995). Training for attentional control in dual-task settings: A comparison of young and old adults. Journal Experimental Psychology Applied, 1(1), 50-76.

65. Kyriacou, C., \& Sutcliffe, J. (1978). Teacher stress: Prevalence, sources and symptoms. British Journal of Educational Psychology, 48, 159-167.

66. Kyriacou, C. (2001). Teacher Stress: Directions For Future Research. Educational Review, 53, 27-35.

67. Leung, D.Y.P., \& Lee, W.W.S. (2006). Predicting intention to quit among Chinese teachers: differential predictability of the components of burnout. Anxiety, Stress \& Coping. An International Journal, 19, 129-141.

68. Locke, E.A. (1976). The Nature And Causes Of Job Satisfaction. In: Dunette MD (eds). Handbook Of Industrial And Organizational Psychology. Chicago: Rand Mcnally, Pp. 1297-1343.

69. Lyness, K.S., \& Thompson, D.E. (1997). Above the glass ceiling? A comparison of matched samples of female executives. Journal of Applied Psychology, 82(3), 359-375.

70. Mahdi, A.F., Zin, M.Z.M., Nor, M.R.M., Sakat, A.A., \& Naim, A.S.A. (2012). The relationship between job satisfaction and turnover intention. American Journal Of Applied Science, 9(9), 1518-1526.

71. Manthei, R., Gilmore, A., Tuck, B., \& Adair, V. (1996). Teacher stress in intermediate schools. Educational Research, 38 (1), 3-19.

72. Maslach, C., Schaufeli, W.B., \& Leiter, M.P. (2001). Job burnout. Annual Review of Psychology, 52, 397-422.

73. McCormick, C.M., Merrick, A., Secen, J., \& Helmreich, D.L. (2006). Social instability in adolescence alters the central and peripheral hypothalamic-pituitary-adrenal responses to a repeated homotypic stressor in male and female rats. Journal of Neuroendocrinology, 19(2),116-126.

74. McBey, K., \& Karakowsky, L. (2001). Examining sources of influence on employee turnover in the part-time work context. Career Development International, 6(1), 39-48.

75. Menlo, A., \& Poppleton, P. (1990). A Five Country Study of the Work Perceptions of Secondary School Teachers in England, the United States, Japan, Singapore and West Germany (1986-88), in: Comparative Education, 26(2), 173-182.

76. Michaelowa, K., \& Wittmann, E., (2002). Teacher Job Satisfaction, Student Achievement and the Cost of Primary Education - Evidence from Francophone Sub-Saharan Africa, HWWA Discussion Paper, Hamburg Institute of International Economics.

77. Mobley, W.H., Horner, S.O., \& Hollingsworth, A.T. (1978). An evaluation of precursors of hospital turnover. Journal of Applied Psychology, 63(4), 408-414.

78. Mondal, J., Shrestha, S., \& Bhaila, A. (2011). School teachers: job stress and job satisfaction. International Journal of Occupational Safety and Health, 2011(1),27-33.

79. Moore, K.A. (2001). Hospital restructuring: impact on nurses mediated by social support and a perception of challenge. Journal Of Health And Human Services Administration, 23(4), 490-517.

80. Mohammed, M.A. (2000). Teacher stress. Unpublished dissertation Physical Education College in Cairo.

81. Muindi, F.K. (2011). The relationship between participation in decision making and job satisfaction among academic staff in the school of business. Journal Of Human Resources Management Research, 2011, 1-34.

82. Murad, S. (1997). Stress for teachers. Education College Magazine, 29, Al Zagazig University,Al Zagazig, Egypt.

83. Nagar, K. (2012). Organizational commitment and job satisfaction among teachers during times of burnout. Vikalpa the Journal for Decision Makers, 37(2), 43-60. 
84. Netemeyer, R.G., Boles, J.S., \& McMurrian, R. (1996). Development and validation of work family conflict and family-work conflict scales. Journal of Applied Psychology, 81(4), 400-410.

85. Nurmayanti,S., Thoyib, A., Noermijati, \& Irawanto, D. (2014). Work Family Conflict: A Review of Female Teachers in Indonesia, International Journal of Psychological Studies; 6, 4, Published by Canadian Center of Science and Education.

86. O'Driscoll, M.P., Ilgen, D.R., \& Hildreth, K. (1992). Time devoted to job and off-job activities, inter role conflict, and affective experiences. Journal of Applied Psychology, 77(3), 272-279.

87. Olorunfemi, D.Y. (2009). Family-Work Conflict, Information Use, and Social Competence: A Case Study of Married Postgraduate Students in the Faculty of Education, University of Ibadan, Nigeria. Library Philosophy and Practice, 1-7.

88. Panatik, S.A.B., Rajab, A., Shah, I.M., Rahman, H.A., Yusoff, R.M., \& Badri, S.K.B.Z. (2012). Work-Family Conflict, Stress and Psychological Strain in Higher Education. International Conference on Education and Management Innovation, IPEDR vol.30, IACSIT Press, Singapore.

89. Papastylianou, A., Kaila, M., \& Polychronopoulos, M. (2009). Teachers' burnout, depression, role ambiguity and conflict, Social Psychology Education, 12, 295-314.

90. Perrewe, P.L., Hochwarter, W.A., \& Kiewitz, C. (1999). Value attainment: An explanation for the negative effects of work-family conflict on job and life satisfaction. Journal of Occupational Health Psychology, 4(4), 318-326.

91. Price, J.L., \& Mueller C.W. (1981). A casual model of turnover for nurses. Academy of Management Journal, 24(3), 543-565.

92. Saks, A.M. (1996). The relationship between the amount and helpfulness of entry training and work outcomes. Human Relations, 49, 429-451.

93. Schermerhorn, J.R., Hunt, J.G., \& Osborn, R.N. (1994). Managing Organizational Behavior. (Fifth Ed.), America: John Wiley and Sons Inc.

94. Shapira-Lishchinsky, O., \& Rosenblatt, Z., (2009). Organizational Ethics and Teachers' Intent to Leave: An Integrative Approach. Educational Administration Quarterly, 45(5), 725-758.

95. Shore, L.M., \& Martin, H.J. (1989). Job satisfaction and organizational commitment in relation to work performance and turnover intentions. Human Relations, 42(7), 625- 638.

96. Schuller, R., Aldag, R., \& Brief, A.P. (1977). Role conflict and ambiguity a scale analysis. Organizational Behavior and Human Performance, 20, 111-28.

97. Shyman, E., (2010), Identifying Predictors Of Emotional Exhaustion Among Special Education Paraeducators: A Prelımınary Investıgatıon, Psychology in the Schools, 47(8), 828-841.

98. Skaalvik, E.M., \& Skaalvik, S. (2010). Teacher self-efficacy and teacher burnout: A study of relations. Teaching and Teacher Education, 26, 1059-1069.

99. Somech, A, Drach-Zahavy, A. (2000). Understanding extra-role behavior in schools: the relationships between job satisfaction, sense of efficacy, and teachers' extra-role behavior. Teaching and Teacher Education,16, 649659.

100.Spector, P. (1997). Job satisfaction: application, assessment, causes and consequences. California: Sage.

101. Statistical Analysis Report, (1997), Job Satisfaction Among America's Teachers: Effects of Workplace Conditions, Background Characteristics, and Teacher Compensation, National Center For Education Statistics.

102.Sutton, R. (1984). Job stress among primary and secondary school teachers: its relationship to ill-being. Work and Occupations, 11, 7-28.

103.Sutton, R.E., \& Wheatley, K.F. (2003). Teachers' emotions and teaching: A review of the literature and directions for future research. Educational Psychology Review, 15, 327-358.

104.Taylor, J., \& Bowers D.G. Survey of Organizations: A Machine-scored Standardized Questionnaire Investment. University of Michigan, Ann Arbor, MI, 1972.

105.Tett, R.P., \& Meyer, J.P. (1993). Job satisfaction, organizational commitment, turnover intention, and turnover: path analyses based on meta-analytic findings. Personnel Psychology, 46, 259-293.

106. Troman, G. (2000). Teacher stress in a low-trust society. British Journal of Sociology of Education, 21, $331-353$.

107.Tsigilis, N., Zournatzi, E., \& Koustelios, A. (2011) Burnout among physical education teachers in primary and secondary schools. International Journal of Humanities and Social Science, 1(7), 53-58.

108.Wafula, A.N. (2010). Work-Family Conflict Among Women From a Collectivistic Culture. MA minithesis, Department of Industrial Psychology, University of the Western Cape.

109.Welsh, J.A., \& Bierman, K.L. (2002). Social competence. Gale Encyclopaedia of Childhood and Adolescence. 
110.Wharton, A.S. (1993). The affective consequences of service work. Work and Occupations, 20, 205-232.

111.www.wikipedia.org, "Workload", http://en.wikipedia.org/wiki/Workload. (12.11.14).

112.Zhang, Q., \& Zhu, W. (2008). Exploring emotion in teaching: Emotional labor, burnout and satisfaction in Chinese higher education. Communication Education, 57 (1), 105-122. 